\title{
Arahan Penataan Kawasan Permukiman Kumuh di Kelurahan Kuin Utara Kota Banjarmasin sebagai Upaya Pembentukan Identitas Kawasan
}

\author{
Muhammad Ahrishar dan Haryo Sulistyarso \\ Departemen Perencanaan Wilayah dan Kota, Fakultas Arsitektur Desain dan Perencanaan, \\ Institut Teknologi Sepuluh Nopember (ITS) \\ e-mail: haryo.its@gmail.com
}

\begin{abstract}
Abstrak-Fenomena kumuh yang terdapat di Kelurahan Kuin Utara sesuai dengan adanya penetapan SK Walikota Banjarmasin No. 460 Tahun 2015 menjadikan kawasan yang merupakan cikal bakal pertumbuhan Kota Banjarmasin ini mulai kehilangan jati dirinya. Hal ini cukup memprihatinkan mengingat Kampung Kuin merupakan kawasan tradisional yang masih terdapat bentuk kehidupan budaya sungai yang masih dijalankan oleh masyarakat setempat. Berdasarkan permasalahan tersebut, maka pada kawasan permukiman di Kelurahan Kuin Utara yang umumnya didominasi oleh permukiman tepi sungai perlu diketahui faktor apa saja yang menjadi penyebab kumuh ditinjau dari karakteristik ruang kawasan permukimannya dalam permasalahan pudarnya estetika kawasan. Penelitian ini bertujuan untuk merumuskan arahan penataan kawasan permukiman kumuh di Kelurahan Kuin Utara sebagaimana berupaya memberikan karakter khusus terhadap potensi yang dimiliki kawasan ini sehingga akan membentuk kawasan yang beridentitas. Adapun beberapa tahapan analisa yang dilakukan yaitu penentuan faktor yang berpengaruh dalam permasalahan permukiman kumuh serta faktor yang dapat membentuk citra kawasan melalui analisis Delphi, kemudian identifikasi dan analisis kondisi eksisting untuk mengetahui permasalahan dan potensi yang dimiliki kawasan, dan merumuskan arahan penataan secara deksriptif kualitatif. Dari hasil analisa, terdapat empat faktor yang mempengaruhi permasalahan permukiman kumuh dan pembentukan citra kawasan. Arahan penataan kawasan yang telah dirumuskan secara umum meliputi perbaikan dan peremajaan fisik bangunan yang berorientasi terhadap sungai, peningkatan kualitas lingkungan permukiman tepi sungai, dan pengembangan sarana prasarana kawasan yang dapat menunjang perkembangan kawasan sebagai kampung wisata.
\end{abstract}

Kata Kunci-Permukiman Kumuh, Permukiman Tepi Sungai, Arahan Penataan, Identitas Kawasan.

\section{PENDAHULUAN}

$\mathrm{K}$ OTA Banjarmasin sebagai ibukota provinsi Kalimantan Selatan dikenal luas sebagai 'Kota Seribu Sungai'. Hal ini ditunjukkan dengan kondisi geografis kota yang $40 \%$ dari wilayahnya terdiri dari sungai-sungai besar maupun kecil yang saling berpotongan, dengan dilaluinya kota oleh dua sungai terbesar di Kalimantan, yaitu Sungai Barito dan Sungai Martapura. Keunikan Kota Banjarmasin sebagai kota sungai memberikan karakter khusus dimana budaya sungai menjadi salah satu ciri kehidupan yang menonjol dari masyarakat Banjar [1]. Besarnya fungsi sungai pada saat itu, khususnya sebagai jalur transportasi menjadi saksi bahwa hampir semua tepian sungai-sungai di kota ini memiliki pola permukiman yang dikembangkan berbentuk memanjang di sepanjang tepian sungai dengan orientasi muka bangunan menghadap ke sungai.

Seiring perkembangan zaman, permukiman tersebut mulai mengalami pergeseran orientasi bangunan dimana sungai kini menjadi halaman belakang yang secara tidak langsung memberikan andil besar terhadap sungai yang tidak lain sebagai 'obyek menderita'. Hal ini ditunjukkan oleh pudarnya makna kebudayaan sungai bagi masyarakat Kota Banjarmasin yang ditunjukkan dengan bentuk ketergantungan, pengetahuan, dan kesadaran terhadap sungai yang sudah sangat dimarjinalkan [2].

Berdasarkan adanya SK Walikota Banjarmasin No. 460 Tahun 2015 terkait Penetapan Lokasi Permukiman Kumuh Kota Banjarmasin, menunjukkan dari seluruh kelurahan di Kecamatan Banjarmasin Utara, Kelurahan Kuin Utara memiliki kawasan kumuh terluas yaitu 30,15 Ha yang tersebar di RT 1,2,3,4,5,7,12,13,14. Hal ini sungguh memprihatinkan mengingat kawasan ini sendiri merupakan kawasan cikal bakal terbentuknya Kota Banjarmasin serta masih terdapatnya bentuk kehidupan budaya sungai yang dijalankan oleh masyarakat setempat. Masih eksisnya rumah tradisional menjadi identitas sejarah yang melekat di kawasan ini [3].

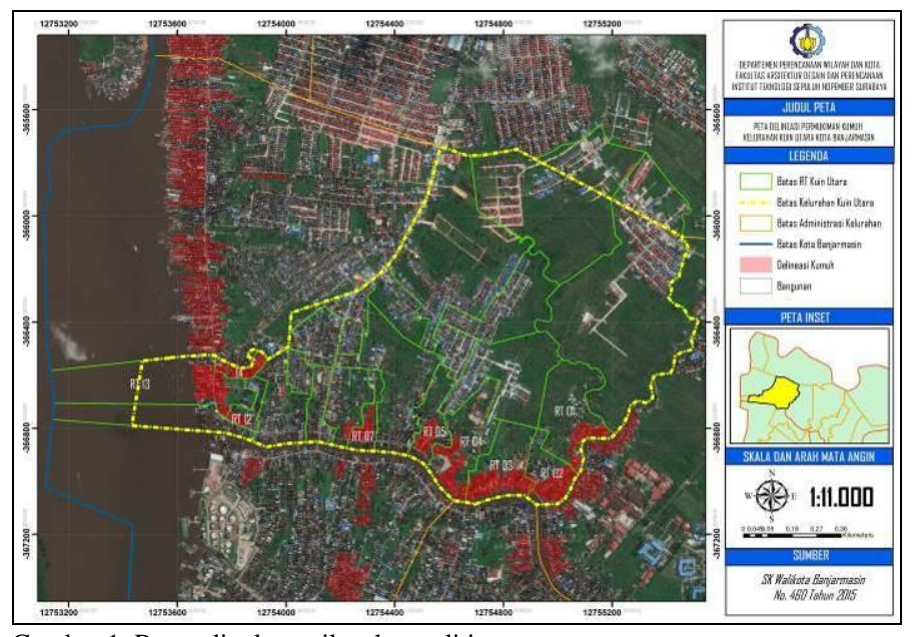

Gambar 1. Ruang lingkup wilayah penelitian. 
Sejalan dengan visi penataan ruang Kota Banjarmasin yang berbasis sungai dalam pembentukan ruang kota, maka diperlukan upaya penataan kawasan kumuh berbasis kearifan lokal di Kelurahan Kuin Utara mengingat realisasi program pemerintah masih jauh dari target penanganan kekumuhan disertai perilaku pengambil kebijakan kota yang semakin mengesampingkan pelestarian budaya lewat pembangunan yang bersifat modern [4]. Mengingat kawasan ini merupakan kawasan yang memegang peranan penting dalam pertumbuhan kota, maka hal mendasar yang diperlukan adalah kegiatan perbaikan serta pengembangan kembali kawasan melalui peningkatan kualitas penataan bangunan dan lingkungan yang mampu memberdayakan aktivitas ekonomi, sosial, dan budaya kawasan. Demikian sudah sepatutnya kegiatan penataan kawasan dapat memberikan karakter khusus lewat potensi yang dimiliki sehingga kawasan tersebut akan mampu menampilkan karakteristik kebudayaan dan menumbuhkan rasa cinta dan kebanggaan terhadap kota yang ditinggali dan ditempati.

\section{METODE PENELITIAN}

\section{A. Metode Pengumpulan Data}

Metode pengumpulan data dilakukan secara primer dan sekunder. Pengumpulan data secara primer dilakukan dilakukan melalui wawancara, kuesioner, dan observasi. Kuesioner digunakan sebagai alat untuk menghimpun data penelitian terkait kondisi karakteristik unit hunian tiap responden dimana jumlah sampel ditentukan berdasarkan perhitungan sampel terhadap data unit rumah yang terdampak kekumuhan yaitu sejumlah 88 sampel responden. Observasi dilakukan untuk mengetahui gambaran kondisi serta karakteristik terhadap masing-masing variabel penelitian, dan wawancara bertujuan menggali informasi terkait bagaimana pengaruh dari tiap faktor berdasarkan pendapat dari tiap stakeholder kunci yang telah ditentukan terhadap permasalahan kekumuhan sesuai topik penelitian. Sedangkan pengumpulan data secara sekunder mulai studi pustaka dan survei instansional sesuai kebutuhan data penelitian.

\section{B. Metode Analisis}

Metode analisis untuk mencapai tujuan penelitian terdiri dari 3 tahapan yaitu melalui analisis terhadap penentuan faktor yang mempengaruhi permasalahan permukiman kumuh berdasarkan karakteristik ruangnya dan faktor yang dapat membentuk citra kawasan, kemudian mengidentifikasi faktor yang membentuk citra kawasan dan analisis kondisi eksisting permasalahan permukiman tepi sungai, selanjutnya perumusan arahan penataan kawasan dalam upaya membentuk identitasnya.

1) Analisa faktor yang berpengaruh terhadap permasalahan permukiman kumuh serta faktor yang berpengaruh terhadap pembentukan citra kawasan

Terhadap faktor beserta variabel penelitian yang telah dirumuskan berdasarkan hasil tinjauan pustaka perlu dilakukan penentuan faktor lebih lanjut yang bertujuan untuk mengeksplorasi serta melakukan konsesus terhadap variabel penelitian yang akan digunakan. Alat analisis yang digunakan yaitu analisis Delphi kepada stakeholder yang sebelumnya telah ditentukan melalui analisis stakeholder. Tahapan-tahapan Delphi yang dilakukan adalah eksplorasi faktor melalui wawancara semi terstruktur kepada responden, hasil eksplorasi kembali diajukan kepada stakeholder sebagai tahap iterasi, dan iterasi dilakukan seterusnya hingga terjadi konsesus.

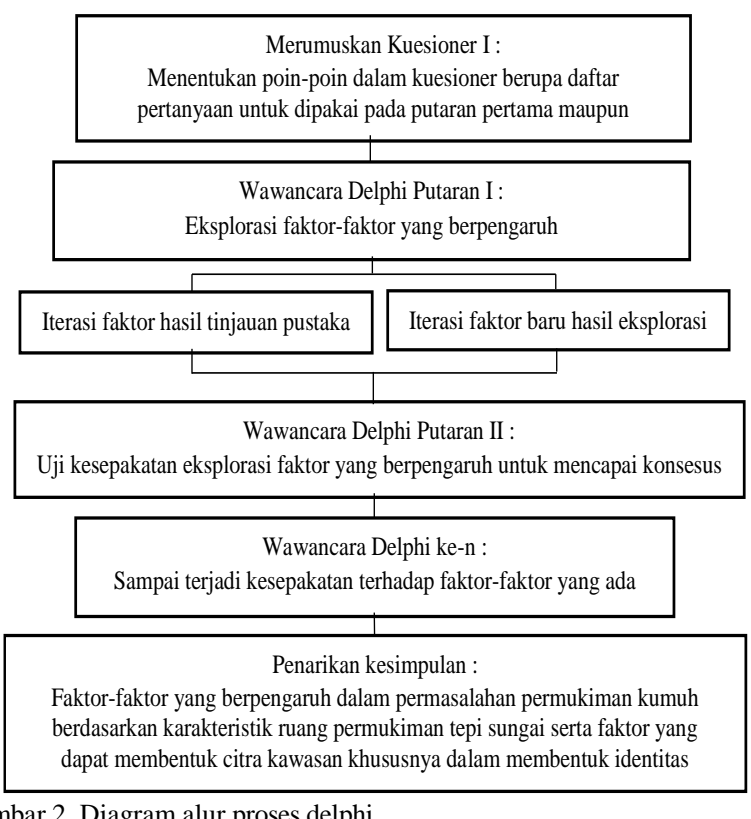

Gambar 2. Diagram alur proses delphi.

2) Identifikasi faktor yang dapat membentuk citra kawasan dan analisis permasalahan eksisting permukiman tepi sungai terkait pudarnya estetika kawasan

Pada hasil penentuan faktor kemudian dilakukan analisis secara deskriptif kualitatif dan kuantitatif. Data tersebut diperoleh dari hasil observasi secara langsung dan penyebaran kuesioner kepada sejumlah responden. Data yang telah diperoleh dijelaskan secara deskriptif dan disajikan dalam bentuk persentase atau proporsi yang divisualisasikan melalui grafik atau chart. Pada sasaran ini yang menjadi hal utama ialah pengamatan dilakukan pada elemen yang menjadi potensi fisik \& non fisik kawasan yang berpengaruh terhadap pembentukan citra kawasan. Selain itu, pengamatan terhadap permukiman kumuh didasarkan pada kondisi dan karakteristik permukiman tepi sungai yang berpengaruh terhadap fenomena kekumuhan

3) Merumuskan arahan penataan kawasan permukiman kumuh dalam upaya membentuk identitas kawasan

Tabel 1.

Metode Analisis dalam Perumusan Arahan

\begin{tabular}{cl}
\hline \hline Aspek & \multicolumn{1}{c}{ Analisis } \\
\hline Sumber & $\bullet$ Peneliti sendiri (fakta lapangan) \\
Informasi & $\bullet$ Kajian pustaka
\end{tabular}




\begin{tabular}{cl}
\hline & $\bullet$ Best practices \\
\multirow{2}{*}{ Tujuan } & $\bullet$ Kebijakan \\
Konflik & $\begin{array}{l}\text { Merumuskan bersama-sama untuk mencapai pilihan yang } \\
\text { terbaik karena analisis ini berangkat dari teknik partisipatif }\end{array}$ \\
Validasi & Terdapat kesamaan hal yang dikemukakan \\
\hline \hline
\end{tabular}

Proses analisis ini pada dasarnya dilakukan secara deskriptif kualitatif. Metode ini merupakan serangkaian kajian yang tidak dapat dinyatakan dalam angka dan rumus melainkan dengan kata-kata dan kalimat yang disusun berdasarkan hasil perolehan data dan analisis yang telah dilakukan sebelumnya [5]. Dalam tahap ini, untuk menghasilkan arahan yang relevan dan bersifat lebih spesifik maka diperlukan suatu validasi arahan. Dengan kata lain, diperlukan komparasi untuk menyesuaikan hasil analisis permasalahan terhadap kebijakan, teori, serta best practice terkait.

Dalam proses perumusan arahan terlebih dahulu dilakukan perumusan strategi dimana strategi ini sendiri menjadi acuan dalam lingkup penataan yang bersifat teknis atau mendetail. Strategi perlu dirumuskan agar dapat diketahui konsep maupun pendekatan apa yang tepat dalam memanfaatkan potensi serta menyelesaikan permasalahan yang ada, dan strategi tersebut dapat memberikan gambaran pembentukan identitas kawasan.

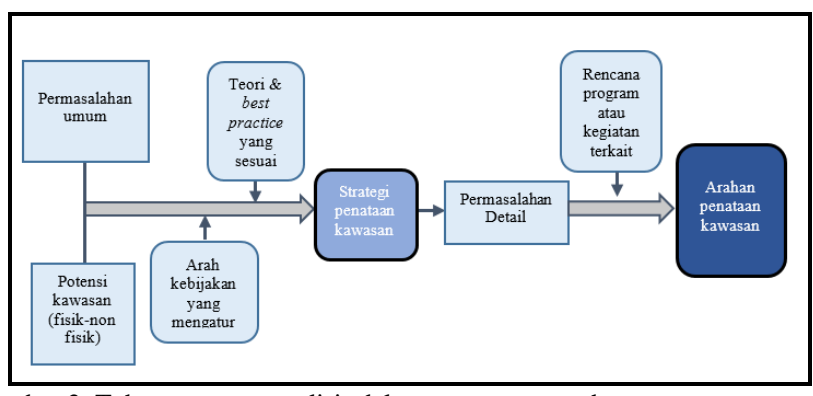

Gambar 2. Tahapan proses analisis dalam perumusan arahan.

Dari proses analisis ini diharapkan akan didapatkan kombinasi yang paling tepat dan implementatif dalam menyusun arahan penataan khususnya aspek fisik, lingkungan, serta sarana prasarana.

\section{HASIL DAN DISKUSI}

A. Faktor-Faktor yang Berpengaruh terhadap Permasalahan Permukiman Kumuh ditinjau dari Karakteristik Ruang Kawasan Permukiman Tepi Sungai serta Faktor yang Berpengaruh terhadap Pembentukan Citra Kawasan

Pada sasaran ini, terlebih dahulu dilakukan eksplorasi faktor beserta variabelnya dan didapatkan hasil koreksi pada 2 variabel penelitian dan tidak adanya penambahan variabel oleh stakeholder terhadap variabel penelitian.

Tabel 2.

Hasil Analisa Delphi Tahap Eksploraasi

\begin{tabular}{ccc}
\hline Variabel & Variabel & \\
sebelum & sesudah & Definisi operasional \\
dikoreksi & dikoreksi & \\
& &
\end{tabular}

\begin{tabular}{ccc}
\hline Nilai arsitektur & Potensi & Jumlah eksistensi bangunan / artefak dengan \\
lokal/ & artefak fisik & elemen arsitektur lokal / tradisional Banjar \\
tradisional & lokal & Potensi fisik \\
Nilai kawasan & Jenis potensi sumber daya alam dan keadaan \\
& dasar & geografis yang dimiliki kawasan \\
\hline \hline
\end{tabular}

Setelah dilakukan tahap eksplorasi faktor kemudian dilakukan tahap wawancara iterasi I untuk memperoleh konsesus antar stakeholder penelitian dan didapatkan hasil perbedaan pendapat pada variabel 'Orientasi Bangunan' dan 'Prasarana MCK. Sehingga perlu dilakukan wawancara ulang yaitu tahap iterasi II terhadap 2 variabel ini untuk memperoleh konsesus agar variabel penelitian dapat digunakan lebih lanjut.

Tabel 3.

Hasil kuesioner konsesus iterasi II variabel

\begin{tabular}{|c|c|c|c|c|c|c|}
\hline & \multicolumn{6}{|c|}{ Hasil konsensus (S/TS) } \\
\hline & $\mathrm{R} 1$ & $\mathrm{R} 2$ & R3 & R4 & R5 & R6 \\
\hline \multicolumn{7}{|c|}{ Penurunan estetika kawasan permukiman tepi sungai } \\
\hline Orientasi bangunan & $\mathrm{S}$ & $\mathrm{S}$ & $\mathrm{S}$ & $\mathrm{S}$ & $\mathrm{S}$ & S \\
\hline Penerapan arsitektur lokal / tradisional & S & S & $\mathrm{S}$ & $\mathrm{S}$ & $\mathrm{S}$ & $\mathrm{S}$ \\
\hline $\begin{array}{l}\text { Keberadaan area service pada kegiatan } \\
\text { pemanfaatan sungai (Batang) }\end{array}$ & $\mathrm{S}$ & S & $\mathrm{S}$ & $\mathrm{S}$ & $\mathrm{S}$ & $\mathrm{S}$ \\
\hline $\begin{array}{c}\text { Keberadaan area atau dermaga untuk akses } \\
\text { transportasi sungai }\end{array}$ & S & $\mathrm{S}$ & $\mathrm{S}$ & $\mathrm{S}$ & $\mathrm{S}$ & $\mathrm{S}$ \\
\hline Tingkat kepadatan dan tata bangunan & S & S & $\mathrm{S}$ & $\mathrm{S}$ & $\mathrm{S}$ & $\mathrm{S}$ \\
\hline Fungsi kegiatan bangunan rumah & $\mathrm{S}$ & S & $\mathrm{S}$ & $\mathrm{S}$ & $\mathrm{S}$ & $\mathrm{S}$ \\
\hline $\begin{array}{l}\text { Jalur pedestrian lokal (titian) sebagai jalur } \\
\text { sirkulasi }\end{array}$ & S & $\mathrm{S}$ & $\mathrm{S}$ & $\mathrm{S}$ & $\mathrm{S}$ & $\mathrm{S}$ \\
\hline Ruang terbuka \& rekreasi tepian sungai & $\mathrm{S}$ & $\mathrm{S}$ & $\mathrm{S}$ & $\mathrm{S}$ & $\mathrm{S}$ & $\mathrm{S}$ \\
\hline Pencemaran kawasan bantaran sungai & S & S & $\mathrm{S}$ & $\mathrm{S}$ & $\mathrm{S}$ & $\mathrm{S}$ \\
\hline Prasarana jalan lingkungan & S & S & $\mathrm{S}$ & $\mathrm{S}$ & $\mathrm{S}$ & $\mathrm{S}$ \\
\hline Jaringan & $\mathrm{S}$ & S & $\mathrm{S}$ & $\mathrm{S}$ & $\mathrm{S}$ & $\mathrm{S}$ \\
\hline Prasarana MCK & $\mathrm{S}$ & S & $\mathrm{S}$ & $\mathrm{S}$ & $\mathrm{S}$ & $\mathrm{S}$ \\
\hline Sarana permukiman & $\mathrm{S}$ & S & $\mathrm{S}$ & $\mathrm{S}$ & $\mathrm{S}$ & $\mathrm{S}$ \\
\hline \multicolumn{7}{|c|}{ Identitas dan citra kawasan permukiman tepi sungai } \\
\hline Path (jalur) & $\mathrm{S}$ & $\mathrm{S}$ & S & $\mathrm{S}$ & S & $\mathrm{S}$ \\
\hline Edge (tepian & $\mathrm{S}$ & $\mathrm{S}$ & $\mathrm{S}$ & $\mathrm{S}$ & $\mathrm{S}$ & $\mathrm{S}$ \\
\hline District (kawasan) & S & S & $\mathrm{S}$ & $\mathrm{S}$ & $\mathrm{S}$ & $\mathrm{S}$ \\
\hline Node (simpul) & $\mathrm{S}$ & $\mathrm{S}$ & $\mathrm{S}$ & $\mathrm{S}$ & $\mathrm{S}$ & $\mathrm{S}$ \\
\hline Landmark (tengera & S & S & $\mathrm{S}$ & $\mathrm{S}$ & $\mathrm{S}$ & $\mathrm{S}$ \\
\hline $\begin{array}{c}\text { Kegiatan sosial ekonomi budaya masyarakat } \\
\text { setempat yang khas }\end{array}$ & S & $\mathrm{S}$ & $\mathrm{S}$ & $\mathrm{S}$ & S & $\mathrm{S}$ \\
\hline Warisan sejarah & $\mathrm{S}$ & S & $\mathrm{S}$ & $\mathrm{S}$ & $\mathrm{S}$ & $S$ \\
\hline Potensi artefak fisik lokal & S & S & $\mathrm{S}$ & $\mathrm{S}$ & $\mathrm{S}$ & $\mathrm{S}$ \\
\hline Potensi fisik dasar & $\mathrm{S}$ & $\mathrm{S}$ & $\mathrm{S}$ & $\mathrm{S}$ & $\mathrm{S}$ & $\mathrm{S}$ \\
\hline
\end{tabular}

R1: Barenlitbangda Kota Banjarmasin (Ain Roselly Syahsalina)

R2: Dinas Pekerjaan Umum dan Penataan Ruang (Prita Sulistiani)

R3: Dinas Perumahan dan Kawasan Permukiman (Erpansyah)

R4: Kelurahan Kuin Utara (Endang Anggraeni N.)

R5: Pusat Studi Pembangunanan Permukiman Perkotaan LPPM-ULM (Ira Mentayani)

R6: Tokoh Masyarakat BKM Kuin Utara Membangun (Samsul)

Pada tabel 3, telah diperoleh variabel penelitian yang dapat digunakan pada penelitian untuk mengidentifikasi karakteristik kawasan dan menganalisis permasalahan eksisting sesuai pengaruh dari masing-masing faktor terhadap permasalahan yang muncul di lapangan.

B. Identifikasi Faktor yang Dapat Membentuk Citra Kawasan dan Analisis Permasalahan Eksisting Permukiman Tepi Sungai pada Permukiman Kumuh Kelurahan Kuin Utara terkait Pudarnya Estetika Kawasan

Sebelum menganalisis kondisi eksisting kawasan permukiman tepi sungai terhadap faktor-faktor yang telah ditentukan dan dianggap berpengaruh terhadap permasalahan permukiman kumuh berdasarkan komponen yang menjadi 
karakteristik kawasan permukiman tepi sungainya, terlebih dahulu dilakukan identifikasi terhadap faktor pembentuk citra kawasan. Faktor-faktor tersebut memberikan gambaran karakteristik kawasan yang yang merupakan tanda jati diri yang membedakannya dengan kawasan yang lain.

1) Elemen Keruangan Kawasan Permukiman Tepi Sungai

Citra sebuah kawasan terbentuk oleh ciri khas yang ditekankan oleh lingkungan fisik sehingga memunculkan kesan yang diberikan oleh masyarakat luas terhadap kawasan tersebut. Kelima elemen pokok sesuai teori citra kota yang dikemukakan oleh Kevin Lynch [6] dapat membangun gambaran visual seseorang terhadap suatu kota. Pentingnya elemen ini terletak pada kenyataan bahwa seseorang selalu berpikir tentang bentuk kota atas dasar kelima elemen pokok tersebut.

\section{a) Path}

Berdasarkan hasil pengamatan, elemen path yang ditemukan berupa 1) jalan lokal sebagai jalur akses sirkulasi utama masyarakat di daratan, 2) jalan lingkungan pada gang-gang permukiman warga, 3) sungai sebagai jalur sirkulasi masyarakat di perairan sungai, 4) jembatan sebagai jalur penghubung wilayah daratan, dan 5) titian sebagai jalur pejalan kaki bagi masyarakat di daratan yang hendak melakukan aktivitas di kawasan bantaran sungai.
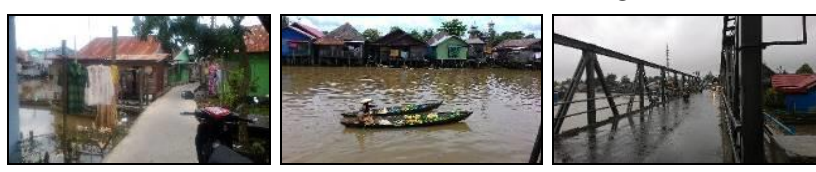

Gambar 3. Elemen path pada kawasan permukiman tepi sungai Kelurahan Kuin Utara.

Secara keseluruhan, keberadaan elemen path berkembang mengikuti keadaan geografis di kelurahan ini. Jalur di darat seperti jalan dan jembatan mengikuti keadaan jalur sungai sehingga mengakibatkan pola yang berkembang pada mayoritas permukiman tidak teratur seperti pada umumnya perumahan formal.

\section{b) Edge}

Berdasarkan hasil pengamatan, elemen edge (tepian) yang ditemukan berupa 1) sungai besar sebagai elemen pemisah antara 2 kawasan secara fisik maupun administratif dan 2) areal persawahan sebagai area tak terbangun yang membatasi lingkungan kawasan permukiman secara fisik.
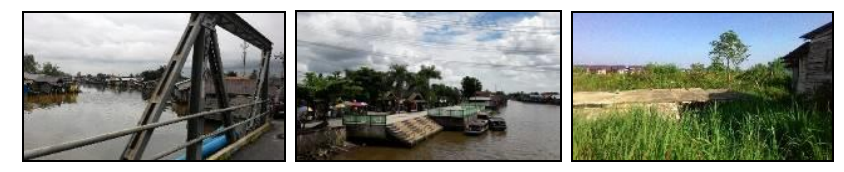

Gambar 4. Elemen edge pada kawasan permukiman tepi sungai Kelurahan Kuin Utara.

Peran sungai sebagai unsur elemen tepian yang membatasi kawasan menjadi ciri khas utama dimana pola permukiman dan jalur sirkulasi darat di tepian sungai mengikuti bentuk sungai tersebut. Dengan komponen arsitektur tepian sungai yang terbentuk serta masih eksisnya kehidupan dan kegiatan yang berorientasi pada sungai maka sudah seharusnya permukiman tradisional ini menjadikan sungai sebagai orientasi tata letak.

\section{c) District}

Berdasarkan hasil pengamatan, terdapat kawasan tertentu yang dapat digolongkan dengan kesamaan karakteristik oleh aktivitas yang dilakukan yaitu kawasan perdagangan untuk olahan kerupuk lokal yang terdapat pada RT 7, dan kawasan bersejarah untuk wisata religi yang terletak pada area Makam Sultan Suriansyah yang didukung oleh keberadaan Masjid Sultan Suriansyah. Keberadaan elemen ini mampu menjadi daya tarik wisata lewat kegiatan yang dilakukan.
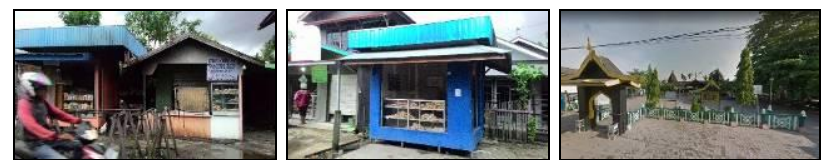

Gambar 5. Elemen district pada kawasan permukiman tepi sungai Kelurahan Kuin Utara.

d) Node

Node merupakan simpul atau lingkaran daerah strategis dimana arah atau aktivitasnya saling bertemu dan dapat diubah kearah atau aktivitas lain. Berdasarkan hasil pengamatan, elemen node yang ditemukan berupa persimpangan jalan yang menyatu dengan jembatan, dan dermaga transportasi sungai sebagai sarana masyarakat menyandarkan perahu untuk beraktivitas dari darat ke sungai atapun sebaliknya.
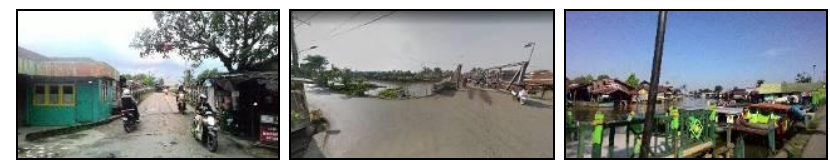

Gambar 6. Elemen edge pada kawasan permukiman tepi sungai Kelurahan Kuin Utara.

Titik simpul node berupa pesimpangan yang menghubungkan antar dua kawasan berbeda mampu menjadi acuan orientasi masyarakat dalam melakukan pergerakan di kawasan ini dimana keberadaan jembatan pada titik simpul tersebut dapat berfungsi sebagai gerbang untuk memasuki kawasan ini

\section{e) Landmark}

Berdasarkan hasil pengamatan, elemen landmark sebagai ikon visual yang cukup menonjol di Kelurahan Kuin Utara berupa gapura kampung wisata yang menunjukkan bahwa kawasan ini memiliki serangkaian obyek wisata baik wisata religi pada situs bersejarah hingga wisata pasar terapung di muara Sungai Kuin, dan Masjid Sultan Suriansyah yang sangat mencolok dengan arsitektur khas Banjar yang masih dipertahankan dan mampu menjadi ikon yang mencirikan kampung kuin sebagai kampung bersejarah.
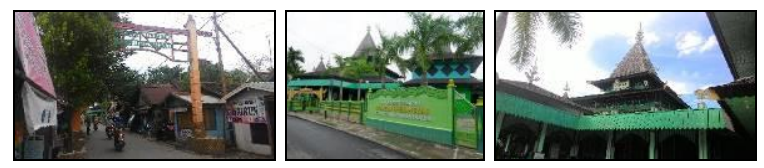

Gambar 7. Elemen landmark pada kawasan permukiman tepi sungai Kelurahan Kuin Utara.

2) Keunikan, Karakter, dan Kekhasan Khusus yang Dimiliki Kawasan

Manusia akan mampu merasakan keunikan sebuah kota lewat keunikan dan kekhasan kehidupan sosial, budaya, ekonomi penghuninya. Di samping itu, sebuah kota sebagai struktur lingkungan fisik mempunyai potensi dan kekayaan 
alam yang menunjang kehidupan penduduknya baik lewat keadaan geografis maupun sumber daya alam yang dimiliki.

a) Kegiatan sosekbud masyarakat

Di Kelurahan Kuin Utara terdapat berbagai jenis industri kecil/ kerajinan yang terdapat di beberapa lingkungan RT seperti industri pengolahan makanan berupa olahan kerupuk ikan lokal dan industri pengolahan kerajinan tanggui dan tajau. Walaupun industri ini bergerak dalam skala kecil namun kegiatan tersebut masih dapat eksis dan mempertahankan teknik pembuatan tradisional yang menjadi potensi ekonomi lokal dan ciri khas tersendiri. Selain itu, keberadaan Pasar Terapung Muara Kuin yang berada di Sungai Barito (muara Sungai Kuin) dengan aktivitas perdagangan yang dilakukan di atas sungai menggunakan jukung (perahu) menjadi pemandangan sangat unik dan menjadi keistimewaan bagi kawasan ini.
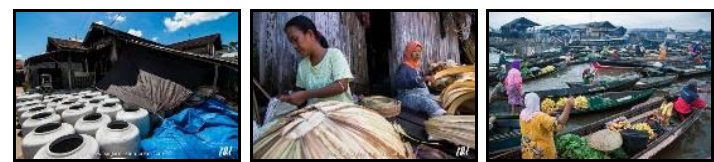

Gambar 8. Kegiatan perekonomian yang mampu menjadi daya tarik kawasan.

b) Warisan sejarah

Di Kelurahan Kuin Utara dapat ditemui 2 situs bersejarah yang cukup dikenal oleh masyarakat yaitu Masjid Sultan Suriansyah dan Kompleks Makam Sultan Suriansyah. Merupakan masjid tertua di Kalimantan dimana bagian-bagian masjid masih menunjukkan corak arsitektur dan interior khas Banjar yang turut terjaga keasliannya ditambah dengan keberadaan makam Raja Kerajaan Banjar pertama yang menjadi bukti fisik sejarah perkembangan kawasan Kampung Kuin dari masa Kerajaan Banjar hingga sekarang.
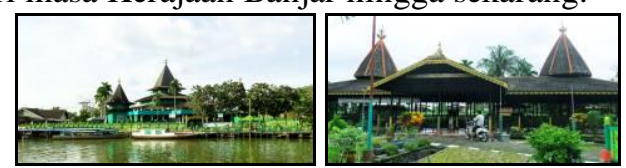

Gambar 9. Makam dan Masjid Sultan Suriansyah.

c) Potensi artefak fisik lokal

Dari berbagai ciri arsitekturalnya, terdapat berbagai jenis tipe bangunan rumah tradisional Banjar yang berkembang dari masa lalu. Berdasarkan hasil identifikasi dapat ditemukan sekitar 6 rumah tradisional Banjar baik dalam kondisi yang masih atau kurang baik, mengalami perubahan, dan telah rusak.
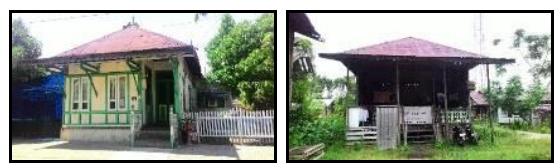

Gambar 10. Eksistensi rumah tradisional Banjar di Kelurahan Kuin Utara.

\section{d) Potensi fisik dasar}

Secara umum, kondisi alam Kota Banjarmasin tergolong minim sumber daya alam karena tidak ditemukan potensi tambang, hutan, maupun pertanian, demikian pula kondisi alam di Kelurahan Kuin Utara. Maka sungai lah yang menjadi sumber daya utama bagi masyarakat. Sesuai dengan arah pembangunan kota, sungai bukan hanya sebagai lokasi drainase dan sumber daya air, melainkan juga sebagai sarana transportasi, komunikasi, dan objek perekonomian masyarakat sehingga secara keseluruhan sungai dapat menjadi modal untuk membangun kemajuan kawasan ini.

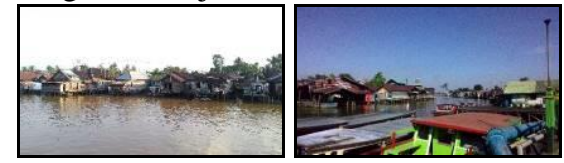

Gambar 11. Sungai sebagai potensi sumber daya alam utama masyarakat di Kelurahan Kuin Utara.

\section{3) Kondisi Fisik dan Lingkungan}

Faktor-faktor yang dibahas berkaitan dengan kondisi fisik dan lingkungan dalam konteks terjadinya penurunan estetika kawasan yang dianggap dapat mengakibatkan munculnya fenomena kekumuhan, dan akibat kekumuhan yang terjadi maka dianggap pula bahwa kawasan permukiman tepi sungai tersebut sudah mulai kehilangan karakternya. Perlu diketahui bagaimana kondisi permukiman di Kelurahan Kuin Utara terhadap kondisi ideal dalam membentuk karakter ruang kawasan permukiman.

\section{e) Orientasi Bangunan}

Kondisi orientasi bangunan berperan penting dalam meningkatkan estetika kawasan dikarenakan aktivitas di perairan sungai pada umumnya masih ramai. Keberadaan teras rumah yang menghadap sungai secara tidak langsung dapat mengubah perilaku bermukim masyarakat dalam menghargai keberadaan sungai. Berdasarkan hasil survey terhadap 88 responden unit hunian, hanya 3 responden (3\%) yang memiliki orientasi bangunan terhadap sungai mengartikan sungai kini hanya dimanfaatkan sebagai area atau halaman belakang.

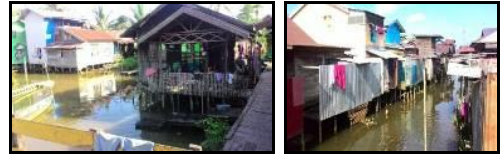

Gambar 12. Kondisi orientasi bangunan di tepi sungai.

\section{f) Penerapan arsitektur lokal/tradisional}

Penerapan arsitektur lokal pada bangunan rumah menunjukkan adanya warisan kebudayaan yang berkembang pada suatu kawasan. Kondisi ini diamati lewat bagaimana kondisi fisik bangunan melalui ciri arsitekturnya (jenis konstruksi, penggunaan material, komponen, ornamen, dll). Berdasarkan hasil survey, seluruh jenis konstruksi menggunakan konstruksi kayu, dengan penggunaan material kayu pada dinding dan lantai rumah masih mendominasi, namun pada material atap mengalami modifikasi menggunakan material seng sebagai pengganti sirap yang merupakan ciri khas rumah Banjar. Selain itu tingkat keberadaan ornamen khas Banjar yang menghiasi bangunan rumah hanya berkisar $11 \%$. Secara umum, kondisi bangunan masih mempertahankan arsitektur lokal dengan jenis rumah panggung, namun permasalahan utama adalah kualitas fisik bangunan yang kurang sehingga menyebabkan tingkat kenyamanan dan keamanan yang rendah dalam menghuni bangunan tersebut 


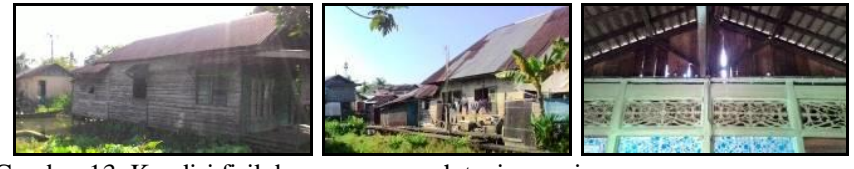

Gambar 13. Kondisi fisik bangunan rumah tepi sungai.

\section{g) Keberadaan area Batang}

Masih banyaknya aktivitas masyarakat yang dilakukan di sungai menjadikan batang sebagai sarana interaksi sosial bagi masyarakat terhadap sungai. Berdasarkan jumlahnya, terdapat sebanyak 9 unit rumah responden (10\%) yang memiliki area batang di sekitar rumahnya sebagai ruang interaksi dalam kegiatan pemanfaatan sungai seperti kegiatan mencuci, jual beli ,tempat bersantai, hingga akses transportasi. Menunjukkan bahwa tingkat keberadaannya pada saat ini cukup rendah dan jarang ditemui dikarenakan perkembangan aktivitas yang lebih mengarah ke daratan.

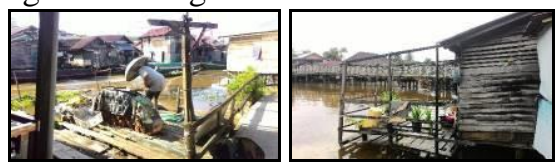

Gambar 14. Kondisi area batang sebagai ruang sarana interaksi di tepian sungai.

h) Keberadaan area atau dermaga lokal

Transportasi sungai masih menjadi salah satu mobilitas transportasi bagi masyarakat setempat. Keberadaan area atau dermaga lokal pada unit rumah dan lingkungan sekitar sangat penting sebagai salah satu sarana yang berfungsi menghubungkan kegiatan di darat dan di sungai. Berdasarkan hasil survey primer, diketahui sebanyak 20 unit rumah responden (23\%) memiliki area untuk bertambatnya perahu di sekitar rumah mereka yang umumnya bersifat sederhana tanpa adanya tempat khusus yang berfungsi sebagai garasi perahu. Adapun selain itu terdapat 2 unit dermaga publik yang terletak di tepian sungai Kuin namun tidak berfungsi optimal.
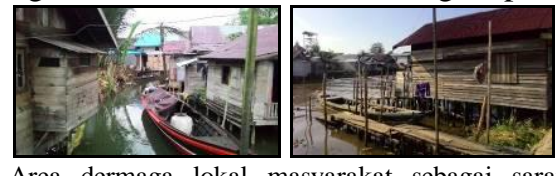

Gambar 15. Area dermaga lokal masyarakat sebagai sarana pendukung transporasi sungai.

i) Tingkat kepadatan dan tata bangunan

Sebuah lingkungan permukiman yang berdesakan dan tidak teratur mencerminkan lingkungan yang tidak sehat dan baik bagi masyarakat yang berada di lingkungan tersebut. Berdasarkan data profil permukiman kumuh di Kelurahan Kuin Utara dapat diketahui kondisi kepadatan bangunan, dimana:

Kepadatan Tinggi (>100 unit/Ha) : RT 5 dan 12

Kepadatan Sedang (80-100 unit/Ha) : RT 1 dan 2

Kepadatan Rendah (<80 unit/Ha): RT 3,4,7,13, dan 14

Rata-rata tingkat kepadatan bangunan yaitu sebesar 75,57 unit/Ha.

Selain itu, kondisi sebagian besar bangunan di bantaran sungai memiliki kerapatan yang cukup tinggi dengan jarak berkisar kurang dari 1 hingga 2 meter antar bangunan rumah. Hal ini tentunya menunjukkan kondisi lingkungan permukiman yang kurang baik, namun di satu sisi menunjukkan bagaimana kekerabatan masyarakat yang terjalin.

\section{j) Fungsi kegiatan bangunan rumah}

Bangunan rumah yang tidak hanya difungsikan sebagai hunian melainkan juga sebagai sarana perdagangan jasa, industri rumahan, dan lainnya, berpotensi untuk merubah tampilan fisik bangunan serta mencemari lingkungan sekitar. Dari hasil rekapitulasi kuesioner dapat diketahui bahwa terdapat 20 unit rumah responden (23\%) yang memiliki fungsi lain sebagai sarana perdagangan dan jasa, dan 1 unit rumah responden (1\%) sebagai sarana industri rumahan. Permasalahan yang ditemui terkait kondisi bangunan akibat kegiatan lainnya adalah tampilan wajah bangunan yang tidak tampak karena kebutuhan untuk menempatkan usaha pada bagian depan rumah sehingga menimbulkan kesan lingkungan permukiman yang kurang baik.
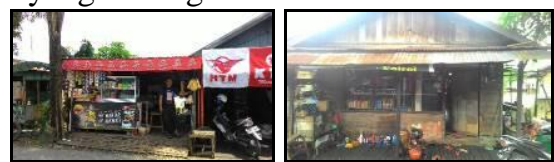

Gambar 16. Gambaran kondisi bangunan dengan fungsi kegiatan lainnya pada bangunan rumah.

\section{k) Jalur pedestrian lokal (titian)}

Titian adalah jalur pedestrian lokal yang dibangun di atas air atau tanah rawa dimana pada umumnya dibangun dengan menggunakan konstruksi tiang dengan lantai dari susunan kayu (papan) yang memanjang, dan merupakan suatu kearifan lokal yang cukup melekat sebagai ciri khas kawasan. Hasil survey menunjukkan bahwa sebanyak 37 unit rumah responden $(42 \%)$ terdapat titian sebagai jalur sirkulasi yang melengkapi lingkungan tepi sungai mereka. Namun sebagian besar menunjukkan kondisi yang kurang baik dengan kualitas kayu yang cukup rapuh.

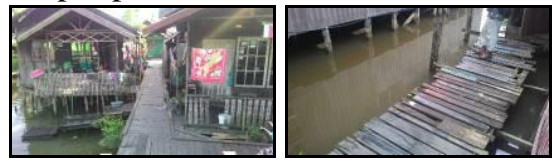

Gambar 17. Gambaran kondisi jalur titian pada lingkungan permukiman tepi sungai.

1) Ruang terbuka dan rekreasi tepian sungai

Keberadaan ruang terbuka publik pada tepian sungai merupakan komponen yang penting untuk turut meningkatkan estetika kawasan tepian sungai yang juga dapat menjadi sarana masyarakat untuk berekreasi atau berwisata. Di Kelurahan Kuin Utara terdapat 3 ruang terbuka yang terletak di tepian sungai Kuin yang juga difungsikan sebagai dermaga dan di tepian sungai Jagabaya sebagai taman lingkungan RT. Secara keseluruhan kondisi ruang terbuka tersebut tidak memiliki elemen activity support yang dapat mendukung berbagai kegiatan yang dapat dilakukan pada sebuah ruang terbuka.

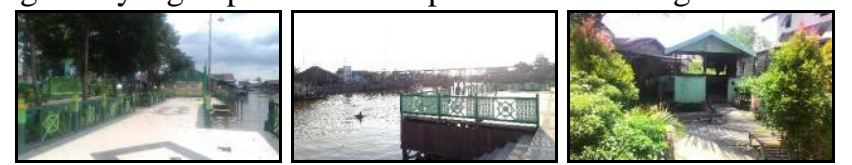

Gambar 18. Ruang terbuka tepian sungai di Kelurahan Kuin Utara.

m) Pencemaran kawasan bantaran sungai 
Akibat perubahan pola perilaku masyarakat yang kurang menjaga kelestarian lingkungan, sungai justru menjadi tercemar khususnya oleh limbah domestik yang mengakibatkan kualitas air sungai semakin memburuk kian harinya. Dari hasil observasi, diperoleh hasil bahwa hampir seluruh unit rumah responden yaitu sebanyak 81 unit rumah (92\%) terdapat pencemaran air sungai di sekitar rumah oleh sampah domestik menunjukkan kondisi kebersihan sungai yang kurang terjaga, walaupun pada sebagian kecil kondisi masyarakat telah berkomitmen untuk menjaga kebersihan sungai.
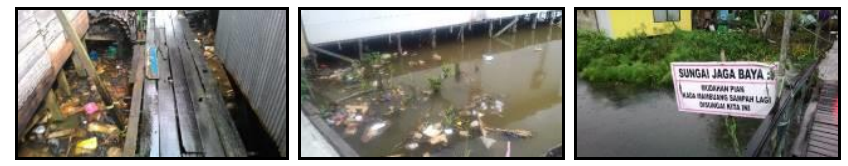

Gambar 19. Kondisi bantaran sungai di Kelurahan Kuin Utara.

4) Kondisi Sarana dan Prasarana Permukiman

a) Prasarana Jalan Lingkungan

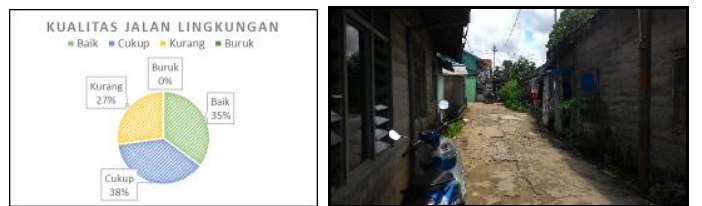

Gambar 20. Persepsi responden terhadap tingkat kualitas jalan lingkungan.

Mayoritas kondisi jalan lingkungan sudah cukup baik dikarenakan adanya program-program perbaikan jalan lingkungan oleh pemerintah kota walaupun pada sebagian kondisi ditemukan lebar jalan yang $<2,5$ meter dan belum adanya perkerasan. Selain itu terdapat jalan lingkungan yang sudah mulai terjadi kerusakan dan perlunya perbaikan kembali.

\section{b) Prasarana MCK}

Dari hasil observasi diketahui bahwa sebanyak 88 unit rumah responden $(100 \%)$ memiliki bentuk fasilitas MCK individu dengan jenis berupa jamban yang merupakan bangunan fisik sederhana (umumnya terbuat dari material kayu) dengan sistem pembuangan limbah lewat pembuangan langsung dimana hasil dari kegiatan MCK dibuang begitu saja ke sungai.

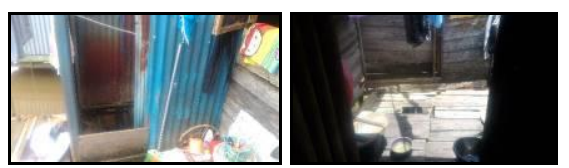

Gambar 21. Kondisi prasarana MCK permukiman tepi sungai berupa jamban.

\section{c) Jaringan Prasarana Dasar}

Jaringan prasarana dasar merupakan kelengkapan dasar fisik lingkungan hunian yang harus memenuhi standar tertentu untuk kebutuhan bertempat tinggal yang layak, sehat, dan nyaman. Berdasarkan hasil observasi kondisi diketahui bahwa terkait prasarana air bersih sebagian besar $(90 \%)$ masyarakat telah memiliki sambungan air bersih ke dalam rumah, namun untuk jaringan drainase mayoritas dengan sistem pembuangan langsung tanpa adanya saluran samping jalan, selain itu masih kurangnya penyediaan sarana tempat pembuangan sampah baik oleh lingkungan RT setempat maupun pemerintah, serta sistem sanitasi dengan pembuangan langsung ke sungai tanpa adanya penggunaan septic tank.

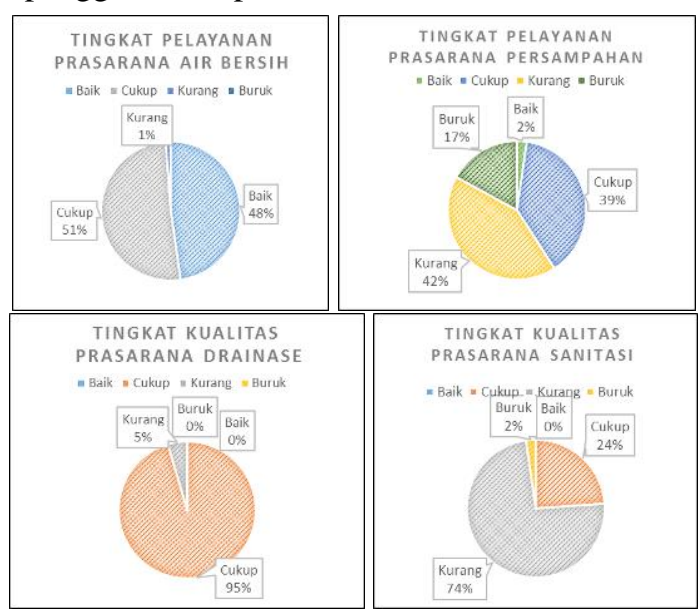

Gambar 22. Persepsi responden terhadap tingkat pelayanan/kualitas jaringan prasarana dasar.

\section{d) Sarana Permukiman}

Penyediaan sarana atau fasilitas lingkungan pada kawasan permukiman berperan penting menunjang masyarakat dalam kegiatan sehari-hari. Berdasarkan hasil survey primer, diketahui tidak adanya permasalahan tertentu terhadap kondisi dan penyediaan sarana pendidikan, kesehatan, peribadatan dan perdagangan jasa. Mayoritas responden menilai kondisi fisik dan tingkat pelayanannya sudah cukup baik. Hanya saja masyarakat mengeluhkan kurangnya penyediaan sarana sosial sebagai sarana pendukung kegiatan sosial masyarakat.

Tabel 4.

Arahan Penataan Kawasan Permukiman Kumuh di Kelurahan Kuin UTara

\begin{tabular}{|c|c|c|c|}
\hline Aspek & Strategi & Variabel & Arahan \\
\hline & $\begin{array}{l}\text { Mempertahankan } \\
\text { keberadaan }\end{array}$ & $\begin{array}{l}\text { Orientasi } \\
\text { bangunan }\end{array}$ & $\begin{array}{l}\text { Perbaikan dan peremajaan fisik } \\
\text { bangunan rumah di bantaran } \\
\text { sungai dengan pendekatan ' } 2 \\
\text { sisi' dengan orientasi terhadap } \\
\text { sungai dan jalan }\end{array}$ \\
\hline $\begin{array}{c}\text { Bangunan } \\
\text { Hunian }\end{array}$ & $\begin{array}{l}\text { permukiman tepi } \\
\text { sungai dan } \\
\text { melakukan } \\
\text { perbaikan maupun } \\
\text { peremajaan } \\
\text { bangunan di } \\
\text { sepanjang kawasan }\end{array}$ & $\begin{array}{l}\text { Penerapan } \\
\text { arsitektur } \\
\text { lokal/tradisi } \\
\quad \text { onal }\end{array}$ & $\begin{array}{l}\text { Menerapkan kombinasi elemen } \\
\text { arsitektur tradisional vernakular } \\
\text { dengan konsep modern dan } \\
\text { ornamentasi pada tiap bangunan } \\
\text { rumah untuk menunjukkan ciri } \\
\text { khas lokal bangunan tradisional } \\
\text { Banjar }\end{array}$ \\
\hline Tepi Sungai & $\begin{array}{l}\text { sungai dengan } \\
\text { menerapkan } \\
\text { konsep riverfront } \\
\text { development untuk }\end{array}$ & $\begin{array}{l}\text { Tingkat } \\
\text { kepadatan } \\
\text { dan tata } \\
\text { bangunan }\end{array}$ & $\begin{array}{l}\text { Mempertahankan pola massa } \\
\text { bangunan dan menghentikan } \\
\text { pengendalian pertumbuhan } \\
\text { bangunan baru ke arah sungai }\end{array}$ \\
\hline & $\begin{array}{l}\text { menciptakan } \\
\text { sebuah kawasan } \\
\text { residential } \\
\text { waterfront. }\end{array}$ & $\begin{array}{l}\text { Fungsi } \\
\text { kegiatan } \\
\text { bangunan } \\
\text { rumah }\end{array}$ & $\begin{array}{l}\text { Inventarisasi dampak positif dan } \\
\text { negatif hunian produktif dan } \\
\text { mengarahkan jenis kegiatan } \\
\text { lainnya pada bangunan hunian } \\
\text { sesuai kegiatan yang akan } \\
\text { berdampak positif terhadap unit } \\
\text { hunian maupun lingkungannya }\end{array}$ \\
\hline $\begin{array}{l}\text { Lingkung } \\
\text { an } \\
\text { Permukim } \\
\text { an Tepi }\end{array}$ & $\begin{array}{l}\text { Mempertahankan } \\
\text { nilai-nilai kearifan } \\
\text { lokal di tengah } \\
\text { modernisasi }\end{array}$ & $\begin{array}{c}\text { Jalur } \\
\text { pedestrian } \\
\text { lokal (titian }\end{array}$ & $\begin{array}{llr}\text { Menciptakan } & \text { ruang } & \text { sirkulasi } \\
\text { sempadan } & \text { sungai } & \text { pada } \\
\text { ruang-ruang } & \text { kosong } & \text { di } \\
\text { sempadan sungai dengan konsep }\end{array}$ \\
\hline Sungai & dengan segala & & promenade dengan ciri khas \\
\hline
\end{tabular}




\begin{tabular}{|c|c|c|c|}
\hline Aspek & Strategi & ari & Arahan \\
\hline & $\begin{array}{l}\text { potensi kebudayan } \\
\text { dan warisan }\end{array}$ & & $\begin{array}{l}\text { lokal menggunakan titian kayu } \\
\text { ulin }\end{array}$ \\
\hline & & & Melakukan peremajaan \\
\hline & $\begin{array}{l}\text { kegiatan sosial, } \\
\text { ekonomi, budaya } \\
\text { masyarakat dalam } \\
\text { mewujudkan } \\
\text { kampung wisata } \\
\text { Kuin }\end{array}$ & $\begin{array}{l}\text { Area pada } \\
\text { kegiatan } \\
\text { pemanfaatan } \\
\text { sungai } \\
\text { (batang) }\end{array}$ & $\begin{array}{l}\text { terhadap keberadaan Batang } \\
\text { yang difungsikan sebagai sarana } \\
\text { interaksi masyarakat tanpa } \\
\text { adanya aktivitas sanitasi yang } \\
\text { berpotensi mencemari sungai }\end{array}$ \\
\hline & & $\begin{array}{c}\text { Area } \\
\text { Dermaga } \\
\text { Lokal }\end{array}$ & $\begin{array}{l}\text { Penyediaan dermaga kecil bagi } \\
\text { tiap unit bangunan hunian yang } \\
\text { memiliki perahu kecil yang } \\
\text { bersifat privat }\end{array}$ \\
\hline & $\begin{array}{l}\text { Mewadahi dan } \\
\text { mengintegrasikan } \\
\text { aktivitas } \\
\text { transportasi sungai }\end{array}$ & $\begin{array}{c}\text { Area } \\
\text { Dermaga } \\
\text { Publik }\end{array}$ & $\begin{array}{l}\text { Rehabilitasi dermaga publik di } \\
\text { tepi sungai Kuin dengan ciri } \\
\text { khas arsitektur lokal dan } \\
\text { terintegrasi dengan ruang } \\
\text { terbuka publik }\end{array}$ \\
\hline & $\begin{array}{l}\text { dan darat (land \& } \\
\text { river integrated } \\
\text { transportation) } \\
\text { melalui kegiatan } \\
\text { perbaikan dan } \\
\text { peremajaan sarana } \\
\text { dan prasarana }\end{array}$ & $\begin{array}{l}\text { Ruang } \\
\text { terbuka dan } \\
\text { rekreasi } \\
\text { tepian } \\
\text { sungai }\end{array}$ & $\begin{array}{l}\text { Penyediaan RTH publik di } \\
\text { tepian sungai Kuin sebagai } \\
\text { sarana rekreasi masyarakat pada } \\
\text { titik strategis dan menambahkan } \\
\text { unsur elemen landmark sebagai } \\
\text { ikon visual yang mampu } \\
\text { mencirikan kawasan }\end{array}$ \\
\hline & $\begin{array}{l}\text { pendukung agar } \\
\text { tercipta suasana } \\
\text { tepian sungai yang } \\
\text { nyaman dan indah }\end{array}$ & $\begin{array}{l}\text { Pencemaran } \\
\text { kawasan } \\
\text { bantaran } \\
\text { sungai }\end{array}$ & $\begin{array}{l}\text { Menjaga keberlangsungan } \\
\text { ekosistem sungai dengan } \\
\text { mengendalikan sedimentasi dan } \\
\text { menjaga kebersihan sungai } \\
\text { secara rutin }\end{array}$ \\
\hline \multirow{3}{*}{$\begin{array}{l}\text { Prasarana } \\
\text { Lingkung } \\
\quad \text { an } \\
\text { Permukim } \\
\quad \text { an }\end{array}$} & \multirow{3}{*}{$\begin{array}{l}\text { Menciptakan } \\
\text { sistem pengelolaan } \\
\text { lingkungan yang } \\
\text { terpadu disertai } \\
\text { peningkatan } \\
\text { pelayanan } \\
\text { infrastruktur dasar } \\
\text { yang memadai } \\
\text { pada kawasan } \\
\text { permukiman tepi } \\
\text { sungai }\end{array}$} & $\begin{array}{l}\text { Prasarana } \\
\text { Jalan } \\
\text { Lingkungan }\end{array}$ & $\begin{array}{l}\text { Melakukan perbaikan jalan } \\
\text { lingkungan yang mulai rusak } \\
\text { dan penyesuaian standar } \\
\text { pelayanan jalan lingkungan } \\
\text { yang berlaku pada seluruh } \\
\text { lingkungan permukiman }\end{array}$ \\
\hline & & $\begin{array}{l}\text { Prasarana } \\
\text { MCK }\end{array}$ & $\begin{array}{l}\text { Penyediaan sarana MCK bagi } \\
\text { semua unit hunian tepian sungai } \\
\text { sesuai standar fasilitas hunian } \\
\text { yang layak dan ekologis } \\
\text { terhadap ekosistem sungai }\end{array}$ \\
\hline & & $\begin{array}{c}\text { Jaringan } \\
\text { Prasarana } \\
\text { Dasar }\end{array}$ & $\begin{array}{l}\text { Peningkatan kualitas pelayanan } \\
\text { air bersih, pengelolaan sampah } \\
\text { terpadu melalui penerapan } 3 R \text {, } \\
\text { penyediaan saluran IPAL } \\
\text { sebagai sistem pembuangan } \\
\text { limbah, dan penyediaan saluran } \\
\text { sekunder drainase pada tiap } \\
\text { jalan lingkungan }\end{array}$ \\
\hline $\begin{array}{c}\text { Sarana } \\
\text { Permukim } \\
\text { an }\end{array}$ & $\begin{array}{l}\text { penyediaan dan } \\
\text { fungsi sarana } \\
\text { permukiman } \\
\text { dalam rangka } \\
\text { meningkatkan } \\
\text { kuantitas dan } \\
\text { kualitas sarana } \\
\text { permukiman untuk } \\
\text { menunjang } \\
\text { aktivitas } \\
\text { masyarakat }\end{array}$ & $\begin{array}{c}\text { Sarana } \\
\text { Kawasan } \\
\text { Permukiman }\end{array}$ & $\begin{array}{l}\text { Penyediaan sarana sosial bagi } \\
\text { masyarakat berupa fasilitas } \\
\text { balai warga baik pada lingkup } \\
\text { RT, RW, maupun kelurahan, } \\
\text { serta membangun sentra } \\
\text { pengolahan dan penjualan hasil } \\
\text { kegiatan industri dan kerajinan } \\
\text { oleh masyarakat setempat dan } \\
\text { meletakkannya pada lokasi } \\
\text { strategis }\end{array}$ \\
\hline
\end{tabular}

Sumber: Hasil Analisis, 2018

C. Merumuskan Arahan Penataan Kawasan Permukiman Kumuh di Kelurahan Kuin Utara dalam Upaya Membentuk Identitas Kawasan

Hasil analisis potensi dan permasalahan sebelumnya menjadi input dalam perumusan strategi dan arahan penataan kawasan permukiman kumuh di Kelurahan Kuin Utara.
Adapun, dalam proses merumuskan arahan dilakukan peninjauan terhadap kebijakan melalui dokumen rencana maupun program/kegiatan terkait, yang meliputi RTRW Kota Banjarmasin 2013-2032, RPJM Kota Banjarmasin 2016-2021, Perencanaan Kawasan Kampung Tepi Air Kuin, Kota Banjarmasin, Dokumen Slum Improvement Action Plan Kota Banjarmasin, serta Rencana Penataan Lingkungan Permukiman Kelurahan (RPLP) Kuin Utara, dimana secara keseluruhan, kebijakan maupun rencana program tersebut mendukung terhadap kegiatan penataan kawasan kumuh dan peremajaan kawasan di sepanjang sungai.

1) Strategi dan Arahan Penataan Kawasan Permukiman Kumuh

Melalui hasil analisa permasalahan dan potensi kawasan, serta tinjauan kebijakan maupun berbagai teori dan best practices dalam hal pengembangan kawasan tepian air/sungai [7], dapat dirumuskan arahan penataan berdasarkan 5 strategi yang dirumuskan sebagai arah pembentukan identitas melalui konsep dan pendekatan yang tepat dalam menangani permasalahan.

\section{KESIMPULAN}

Dari hasil penelitian yang dilakukan diperoleh beberapa kesimpulan yaitu:

. Faktor yang menjadi penyebab kekumuhan dalam permasalahan pudarnya estetika pada kawasan permukiman kumuh Kelurahan Kuin Utara meliputi kondisi fisik dan lingkungan serta kondisi sarana dan prasarana permukimannya, sedangkan faktor yang berpengaruh terhadap pembentukan citra kawasan meliputi elemen keruangan yang menggambarkan kondisi ruang kawasan dalam membentuk citranya, serta keunikan, karakter, dan kekhasan khusus yang dimiliki kawasan

2. Kawasan permukiman di Kelurahan Kuin Utara perkembangannya sangat dipengaruhi oleh keberadaan sungai-sungai yang ada dan memiliki berbagai potensi fisik dan non fisik seperti adanya situs bersejarah Kerajaan Banjar, rumah tradisional, serta kegiatan sosial, ekonomi, dan budaya yang mampu menjadi daya tarik yang melekat sebagai kawasan tradisional yang memiliki nilai kearifan lokal

3. Permasalahan permukiman diantaranya mayoritas bangunan di bantaran sungai tidak memiliki orientasi terhadap sungai, kondisi material bangunan yang memprihatinkan dan mengalami kerusakan, tingkat keteraturan bangunan yang rendah dengan kerapatan yang tinggi, serta fungsi kegiatan bangunan rumah yang mempengaruhi kualitas fisik bangunan dan tercemarnya lingkungan sekitar. Selain itu, tingkat keberadaan jalur titian dan area batang sebagai ruang interaksi yang rendah dengan kondisi umumnya kurang baik, area dermaga lokal yang bersifat sederhana, serta minimnya ruang terbuka publik maupun ruang rekreasi pada kawasan tepian sungai 
4. Arahan penataan kawasan yang telah dirumuskan secara umum meliputi perbaikan dan peremajaan fisik bangunan yang berorientasi terhadap sungai, peningkatan kualitas lingkungan permukiman tepi sungai, dan pengembangan sarana prasarana yang dapat menunjang perkembangan kawasan sebagai kampung wisata.

\section{DAFTAR PUSTAKA}

[1] I. Noor, Jukung dan Budaya Sungai. Banjarmasin: IAIN Antasari Banjarmasin, 2007.

[2] I. Mentayani, "Pudarnya Makna Kebudayaan Sungai di Kota Banjarmasin,” Banjarbaru, 2011.
[3] Dahliani, "Eksistensi Rumah Tradisional Banjar sebagai Identitas Kawasan Bersejarah di Kelurahan Kuin Utara Banjarmasin," Banjarbaru, 2014.

[4] S. Syarief, Jika (Aku) Jadi Wali (Nya) Kota, Gagasan Sederhana Menata Banjarmasin Memasuki Abad Keenam. Banjarmasin: Genta Press, 2016.

[5] I. Gunawan, Metode Penelitian Kualitatif, Teori dan Praktik. Malang: Bumi Aksara, 2013.

[6] M. Zahnd, Perancangan Kota Secara Terpadu. Yogyakarta: Kanisius, 1999.

[7] D. M. Wrenn, Urban Waterfront Development. Washington D.C.: Urban Land Institute, 1983. 